\title{
Coral Reefs: Challenges, Opportunities and Evolutionary Strategies for Surviving Climate Change in the Caribbean
}

\author{
RON MAHABIR \\ George Mason University
}

\begin{abstract}
Coral reefs are one of the most diverse marine ecosystems on Earth. They are renowned hotspots of species biodiversity and provide home to a large array of marine plants and animals. Over the past 100 years, many tropical regions' sea surface temperatures have increased by almost $1{ }^{\circ} \mathrm{C}$ and are currently increasing at about $1-2{ }^{\circ} \mathrm{C}$ per century. Corals have very specific thermal thresholds beyond which their temperature sensitive symbiont Zooxanthellae becomes affected and causes corals to bleach. Mass bleaching has already caused significant losses to live coral in many parts of the world. In the Caribbean, the problem of coral bleaching has especially been problematic, with as much as $90 \%$ bleaching in some parts of the Caribbean due to thermal anomalies in some instances. This paper looks at the key role that temperature plays in the health and spatial distribution of coral in the Caribbean. The relationship between coral and symbiont is examined along with some evolutionary strategies necessary to ensure the future survival of coral with the changing climate.
\end{abstract}

\section{Introduction}

Within the Earth's biome, there is a clear correlation between where different plants and animals live and where various environmental factors such as climate, soil, terrain and vegetation are found (Kearney \& Porter, 2009). Marine sub-biomes follow this correlation. Across these systems, specific factors exist which limit the geographic range within which different marine animals and plants can be found. Climate change impacts these various factors and plays a key role in determining changes in marine species distribution (Cheung et al., 2009). Corals have 
very specific niche requirements, which make them extremely vulnerable to both present and future climate change. One niche requirement is temperature, which depends largely on the ability of coral symbionts to tolerate deviation from usual ranges. Although other factors affect coral distribution including light intensity, precipitation and predation, this paper focuses on temperature as it relates to climate change and its impact on coral distribution in the Caribbean. Also, this paper focuses on reef-building corals with the appreciation that other types of coral communities are equally or even more severely threatened by temperature changes. Although other research has addressed this issue or similar topics for some time now, little work has been done from the geographic standpoint of the Caribbean. The main goal is not to give a detailed account of temperature changes and its impact on corals but instead to provide a brief summary of some of the more salient aspects surrounding this issue identified in the literature. It is hoped that this information can be used to help protect, restore and encourage further work as it relates to the study of climate change and its impact on coral systems in the Caribbean region.

In the section "Caribbean coral reef ecosystems," a brief description of corals in the Caribbean and the symbiotic relationship they share with temperature-dependent symbionts is given. "Impact of climate on coral reefs" looks at the influence of climate change on coral distribution and its impact as it relates to temperature deviation, while "Future climate and coral reefs" provides a brief discussion on the future distribution of coral in the Caribbean and possible adaptation strategies. Finally, this paper concludes with an outlook on coral reefs in the Caribbean and provides possible suggestions for ensuring their survival with future changes in climate. 


\section{Caribbean Coral Reef Ecosystems}

Corals are invertebrate animals belonging to the family of sea animals called Cnidaria. Each coral animal on its own is known as a coral polyp with large groups of polyps of the same species often found together. This is mainly due to the process of budding, where polyps make copies of themselves, with colonies expanding over time (ICRI, 2015). Such communities can range from several hundreds to hundreds of thousands of polyps (NOAA, 2015a). Coral polyps use seawater to create a hard calcium carbonate exoskeleton, which over time forms the geologic coral reef structure (Henkel, 2010). The physical structure itself takes centuries to millennia to fully develop by continually building over older colonies (Spalding, Green, \& Ravilious, 2001). The organisms largely responsible for reef building are Scleractinian corals and Hydrocorals (Glynn, 1996). The architecture and functional ecology of coral reefs are primarily controlled by coral, which make up the main structural body of these marine habitats (Garpe, Yahya, Lindahl, \& Öhman, 2006; Cole, Pratchett, \& Jones, 2008). The other two major components of coral reefs are suprabenthic fishes and cryptofauna, which includes organisms that bore into the substrate (mainly sponges, polychaete and sipunculan worms, and bivalves) (Reaka-Kudla, 1997).

Within the stomach and tissue of coral polyps resides Zooxanthellae (Dinoflagellata symbiodinium), a photosynthetic algae that forms a symbiotic partnership with its host polyp (Dubinsky \& Falkowski, 2011). This symbiosis between animal and plant creates a composite organism referred to as coral. Zooxanthellae accept carbon dioxide $\left(\mathrm{CO}_{2}\right)$ excreted from respiring corals and, using sunlight, produce plant sugars through photosynthesis. The oxygen by-product of photosynthesis is then recycled once more by corals in respiration (Mulhall, 2009). Zooxanthellae also receive protection from predators from the corals' hard exoskeleton and help give coral its bright color. The waste product of coral polyps is also processed by Zooxanthellae to retain important nutrients and provides most of the nutritional needs of corals, as much as $98 \%$ 
in some cases (Coral Reef Alliance, 2008). Many species of tropical corals are also heterotrophic, meaning they have the ability to feed on other organisms instead of relying on photosynthesis as their sole source of nutrient intake (Henkel, 2010; Houlbrèque \& FerrierPagès, 2009).

The geographic distribution of coral reefs show a non-random pattern with the majority of reefs located within shallow waters in tropical and subtropical regions of the world (HoeghGuldberg, 2011). Figure 1 shows the geographic distribution of coral reefs worldwide (shown in red) with the Caribbean region highlighted in yellow and shown in greater detail in Figure 2. Figure 1 shows the distribution of coral reefs predominantly located between latitudes of $30^{\circ} \mathrm{N}$ and $30^{\circ}$ S (Dubinsky \& Falkowski, 2011; Mulhall, 2009). Reef distributions account for less than one-tenth of one percent of the world's oceans, an area of approximately $300,000 \mathrm{~km}^{2}$ (Lough, 2008; Mulhall, 2009). Caribbean corals account for about $7 \%$ of total coral reef distribution with an approximate size of $20,000 \mathrm{~km}^{2}$ (Spalding et al., 2001).

\section{Impact of Climate on Coral Reefs}

Present warming of the climate is evident from observations of increases in global average air and ocean temperatures, widespread melting of snow and ice, and rising global average sea level (Golledge et al., 2015; IPCC, 2014; Solomon et al., 2007; Stern, 2007). Fluctuations in climate occurred in the past on a range of different timescales causing organisms and ecosystems to alter their geographic distribution and adapt to such changes in order to survive (Harley et al., 2006; Lough, 2008; Parmesan \& Yohe, 2003). Visible changes in many natural biological and physical systems corresponding with global warming have already been observed to date (IPCC, 2014; Parry, Canziani, Palutikof, van der Linden, Hanson, 2007). 
Several early attempts have been made to better understand the relationship between changes in ocean temperatures and the geographic distribution of coral. Kiessling (2001), for example, analyzed data on ocean temperatures and the latitudinal ranges of coral reefs during the Phanerozoic period (about 450 million years ago to present) and found a weak correlation between them. Kiessling hypothesized that if temperature did play a main role in latitudinal shifts of coral, then this may have occurred during the Cenozoic period (65 million years ago to present) when changes in paleoclimate were in phase with changes of the central tropical zone. A later study by Precht and Aronso (2004) confirmed Kiessling's (2001) hypothesis. That study found that during the early Holocene (10,000 years ago to present), major temperature changes were responsible for latitudinal "shifting" of coral species near the coast of Florida. It should be noted, however, that "shifting" does not mean the physical relocation of coral. Corals must send their larvae into the water currents with the small chance that those currents may carry the larvae to a more favorable environment in which they can anchor and thrive. According to Precht and Aronso, in the early to mid-Holocene (10,000 to 6,000 years ago), Acropora, a reef-building coral in the Caribbean, dominated reefs as far as Palm Beach, Florida (orange zone in Figure 3). Subsequent to this time, cooling of temperature caused a southward latitudinal shift of Acropora (green zone in Figure 3). Evidence of this temperature association came from fossil studies examining both past and present coral tracts with the discovery of Acropora thickets within the last decade in Fort Lauderdale. This suggests an upper latitudinal shifting of Acropora once more.

More recent research has confirmed that warming ocean waters do affect coral by directly impacting the coral symbiont, Zooxanthellae. Zooxanthellae are highly sensitive to temperature changes and usually thrive in temperatures within the range of $23-29{ }^{\circ} \mathrm{C}$, beyond which 
bleaching occurs (Henkel, 2010). This temperature range corresponds with the geographic distribution of corals both within the Caribbean, as shown in Figure 4, and worldwide, as shown in Figure 1. Bleaching results from a decline in Zooxanthellae densities within coral and from the loss of photosynthetic microalgal pigments (Buchheim, 1998; Donner, 2009; Eakin et al., 2010; Glynn, 1991; Lesser, 2007). Reef-building corals usually contain between $1 \times 10^{6}$ and $5 \times 10^{6}$ $\mathrm{cm}^{2}$ of Zooxanthellae and 2-10 $\mu \mathrm{g}$ of chlorophyll $a$ per Zooxanthellae. Bleaching causes corals to typically lose $60-90 \%$ of their Zooxanthellae with each Zooxanthella having $50-80 \%$ losses in photosynthetic pigments (Glynn, 1996). As a result, corals lose their color and become pale, exposing their white exoskeleton. Figure 5 shows an example of coral bleaching. Since coral polyps mainly rely on Zooxanthellae for provision of most of their nutrients, they are starved with an overwhelming reduction in Zooxanthellae densities. This weakens corals and makes them less efficient at competing against macro algae overgrowth (Goreau, Hayes, Clark, Basta, \& Robertson, 1993; West \& Salm, 2003; Wood, 1999).

Various laboratory experiments have confirmed that both high temperatures (Glynn \& D'Croz, 1990; Hoegh-Guldberg \& Smith, 1989) and low temperatures (Brown \& Ogden, 1993; Williams \& Bimkley-Williams, 1990) induce bleaching in corals. If the degree of thermal stress is not too severe, then Zooxanthellae may recover with a regeneration time between 4 and 74 days for Caribbean corals (Wilkerson, Kobayashi, \& Muscatine, 1988). If prolonged or particularly severe, these events may result in partial or complete coral mortality (Brown, 1997; Dove \& Hoegh-Guldberg, 2006). Even if mortality does not occur, bleaching can have other negative impacts that lead to coral decline including reduced coral growth and reproduction and increased susceptibility to disease (McWilliams, Cote, Gill, Sutherland, \&Watkinson, 2005). Other than increases in temperature, many other factors can cause coral to bleach. Some of these 
factors include solar radiation, salinity shock, sedimentation and disease (Brown, 1997; Glynn, 1991). However, retrospective studies have shown that at scales of $100 \mathrm{~km}$ or more, warm ocean temperatures, typically coupled with high subsurface light levels, have been the main trigger for rapid and excessive bleaching (Eakin et al., 2010; Goreau, McClanahan, Hayes, \& Strong, 2000).

Various attempts have been made to determine the thermal thresholds for coral bleaching. Such information is critical in mitigating the impact of bleaching effects. Hoegh-Guldberg (1999) and Donner, Skirving, Little, Oppenheimer, and Hugh-Guldberg (2005) suggest that a variation in sea surface temperatures (SSTs) as little as $1{ }^{\circ} \mathrm{C}$ can induce coral bleaching in the Caribbean. However, many factors make such deterministic assessments difficult. One major factor is that thresholds can vary with location (Goreau et al., 1993; McWilliams et al., 2005) and this becomes even more critical during the seasonal maximums in SSTs (Lough, 2008). It is expected that agents, biotic (living organism) and abiotic (non-living organism), will vary at these locations and impose different levels of influence on the ability of Zooxanthellae to tolerate deviation from normal temperatures. Examples of agents include both variations in symbiont species and barometric pressure, which influence ocean currents (Berkelmans, 2002).

Another key agent acting on thermal stress is exposure time. Fitt and Warner (1995), for example, conducted lab experiments with four different species of Caribbean corals. That study reported that Zooxanthellae losses for different species of coral. Furthermore, each species of coral had different rates of Zooxanthellae loss, ranging from several hours to a matter of days. Substantial Zooxanthellae losses across species occurred when corals were exposed to higher than normal temperatures $\left(32{ }^{\circ} \mathrm{C}\right.$ and $34{ }^{\circ} \mathrm{C}$, depending on species) in natural light for relatively short periods of time. In another experiment, Iglesias-Prieto, Matta, Robins, and Trench (1992) found that substantial losses to Zooxanthellae occurred at temperatures above $30{ }^{\circ} \mathrm{C}$ for the 
symbiont Symbiodinium microadriaticum, a native species to the Caribbean. Goreau et al. (1993) also reported bleaching in the Caribbean following temperatures that reached about $1{ }^{\circ} \mathrm{C}$ above the long-term average $\left(30^{\circ} \mathrm{C}\right)$ in the warmest months (which varied with location) for extended periods. McWilliams et al. (2005), on the other hand, reviewed historical temperature data from 1983 to 1999 and correlated these with bleaching events. They found that an increase as little as $0.1{ }^{\circ} \mathrm{C}$ in regional SSTs resulted in $35 \%$ and $42 \%$ increases in the geographic extent and intensity of coral bleaching. Such studies highlight the complexities involved in determining thermal thresholds for coral bleaching in the Caribbean.

Several studies in the Caribbean have linked fluctuations in temperature to mass bleaching events. In Puerto Rico, for example, analysis of climate data between 1966 and 1995 found a strong correlation between severe bleaching events (1969, 1987, 1990, and 1995) and cumulative ocean heat stress (Wilkinson et al., 1999). The El Niño-Southern Oscillation (ENSO) has also been observed as a major contributor to the bleaching events that occurred in 1982-83 (Wilkinson et al., 1999), 1997-98, (which led to the loss of 16\% of the world's coral) (Mulhall, 2009), and 2002 (Berkelmans, De'ath, Kininmonth, \& Skirving, 2004). In the Caribbean, the most severe instance of coral bleaching occurred in 2005 (Lesser, 2007): during a period lasting more than six months (Rodríguez, Cróquer, Bone, \& Bastidas, 2010), coral surveys detected bleaching of $90 \%$ of corals in the British Virgin Islands, $85 \%$ in the Netherlands Antilles, $80 \%$ in the U.S. Virgin Islands, $66 \%$ in Trinidad and Tobago, and 52\% in the French West Indies (Donner et al., 2005). Figure 6 shows the temporal distribution of bleaching events in the Caribbean from 1985-2006 reported by Eakin et al. (2010). The vertical axis, Degree Heating Weeks (DHW), provides a measure of sustained thermal stress during a twelve week period where the temperature is at least $1{ }^{\circ} \mathrm{C}$ above what is normally expected. Reports of DHW $=4$ 
corresponds with the onset of bleaching, while DHW $>8$ reflects severe bleaching with possible coral mortality. It is clear from Figure 6 that bleaching events increased in severity during the period with 2005 being a climax point (DHW of about 7). In a related study, Donner et al. (2005) used high temporal resolution satellite data collected for the period 1985-2005 to detect and map instances of coral bleaching during this time. However, that study reported much more severe bleaching in 2005 when compared to bleaching for the same year reported by Eakin et al. (2010). As shown by the pink areas in Figure 7, an almost twofold increase was found, with most severe bleaching occurring in islands in the Lesser Antilles. Such quantitative evidence of coral bleaching suggest a continued upward trend in bleaching events with increasing severity.

\section{Future Climate and Coral Reefs}

For more than a decade now, there has been an observed upward rise in SSTs confirmed by myriad studies, which have cross-compared and combined data collected from various sources including satellites, ships, ocean buoys and other instruments (Hoegh-Guldberg, 1999). Such observations have brought about great concern in the coral science community with respect to the long-term health of coral reef ecosystems. In its fifth assessment report, the International Panel on Climate Change (IPCC) adopted four new greenhouse gas concentration trajectories called the Representative Concentration Pathways (RCPs), superseding the previous Special Report on Emissions Scenarios (SRESs). The various RCPs in order of increasing greenhouse gas emissions are RCP 2.6, RCP 4.5, RCP 6 and RCP 8.5. The numerical value accompanying each RCP is measured in watts per square meter $\left(\mathrm{W} / \mathrm{m}^{2}\right)$ and represents the radiative forcing level at which greenhouse gases (GHGs) become stabilized. For example, RCP 2.6, the most conservative of all scenarios, assumes that GHGs will peak at $3.1 \mathrm{~W} / \mathrm{m}^{2}$ by mid-century and then

levels will stabilize at $2.6 \mathrm{~W} / \mathrm{m}^{2}$ around 2100 (NOAA, 2015b). RCP 2.6 assumes that aggressive 
mitigation strategies will be used to curb the increase of GHGs. RCP 8.5, on the other hand, assumes a "business-as-usual" scenario with GHG emission increasing on their present trajectory with no policy changes to reduce emissions (Symon, 2013). The various RCPs predict very different outlooks for the average surface temperature increase, as shown in Table 1. All RCPs predict an increase in global average surface temperature of 0.3 to $4.8^{\circ} \mathrm{C}$ by the late 21 st century. Given the results of a recent study by McWilliams et al. (2005) indicating that a $0.1{ }^{\circ} \mathrm{C}$ increase in SSTs will induce bleaching in the Caribbean, this region is expected to be at serious risk in the near to long-term future.

Even if SSTs rise, will this equate to an increase in severity and frequency of bleaching events? The answer is unclear, as both the severity and the frequency of bleaching depend largely on the ability of coral symbionts to adapt to increasing SSTs (Hoegh-Guldberg, 1999). Some coral species have the ability to resist (withstand disturbance) bleaching, while others have been found to be much more resilient (fast recovery time) (Gates \& Edmunds, 1999; West \& Salm, 2003). Those species with the ability to adapt and recover more quickly from rising SSTs are expected to dominate the marine landscape (Lough, 2008). On the other hand, while there is evidence to support that corals may adapt to increasing temperatures (Baker, Starger, McClanahan, \& Glynn, 2004; Grottoli, Rodrigues, \& Palardy, 2006; Palumbi, Barshis, TraylorKnowles, \& Bay, 2014; Rowan, 2004), the rate of adaptation by the coral symbionts may be superseded by the rate at which the environment changes in response to the rise of SSTs (Hughes et al., 2003). Hoegh-Guldberg (1999) suggests that based on evidence over the past few decades, corals and their Zooxanthellae are not able to acclimate or adapt fast enough to the short, sporadic thermal events typical of recent bleaching episodes. 
In the Caribbean, McWilliams et al. (2005) predicts that bleaching of coral will reach its maximum extent and maximum intensity when regional SSTs anomalies reach $0.97-0.98^{\circ} \mathrm{C}$ and $0.80-0.85{ }^{\circ} \mathrm{C}$, respectively. These results are slightly lower than the more conservative forecasted temperature increases (RCP 2.6 in Table 1), which could result in coral bleaching becoming a severe problem in the Caribbean in the 21st century. Furthermore, using previous SRES scenarios from the third IPCC assessment report, Donner et al. (2005) predicted a rise in SSTs in the Caribbean of 2.2 to $2.3{ }^{\circ} \mathrm{C}$ using the business-as-usual A1B scenario (similar to RCP 8.5). The second $\mathrm{B} 1$ scenario (similar to RCP 4.5), based on the effect of stabilizing $\mathrm{CO}_{2}$ concentration at $550 \mathrm{ppm}$, predicted that temperatures will rise by 1.4 to $1.7^{\circ} \mathrm{C}$ by 2100 . Finally, under the A1B scenario, climate warming over the next 20-30 years could make thermal stress events like 2005 occur biannually. However, if coral symbionts acclimate or adapt to an increased temperature of $1{ }^{\circ} \mathrm{C}$ under the A1B scenario, events such as the 2005 event will be prolonged to once every 5 years until the 2050s or 2060s. Further adaptation of $1.5{ }^{\circ} \mathrm{C}$ will further delay the 5 year re-occurrence until the 2070s to the 2090s (Donner et al., 2005). Of course, such adaptations are dependent on the ability of coral species to adapt (Loya et al., 2001; McClanahan, 2004).

Another possible adaptation to rising SSTs is for corals to switch symbionts to a more adaptive species. Rowan (2004) showed that this is possible between some species. Furthermore, Mieog, Van Oppen, Cantin, Stam, and Olsen (2007) showed that the Acropora millepora coral species have the ability to host more than one symbiont at the same time and, over time, the abundance of each host may change depending on past temperature exposures. That study showed that Acropora millepora was able to switch to a more temperature-tolerant species of Zooxanthellae in order to adapt to increases in temperature in the range of 1 to $1.5{ }^{\circ} \mathrm{C}$. Such 
adaptive measures in coral communities could result in corals becoming more resistant to future thermal stress, further delaying the extinction of such coral (Baker et al., 2004). However, symbiont shuffling comes at a physiological cost and is only possible in a few species of coral (Hoegh-Guldberg, 1999; Mieog et al., 2007). Moreover, Donner et al. (2005) suggests that if coral species become better adapted at increasing their rate of heterotrophic feeding, this will further prolong extinction times.

Some coral species may also be able to make latitudinal shifts to areas where temperatures are more suitable. However, as Precht and Aronso (2004) suggest, this is not common of all species and few observations of this phenomenon have been made in the Caribbean. Also, if SSTs do increase to IPCC-projected estimates (Table 1), there will be little or no areas available fitting current Zooxanthellae temperature ranges as shown in Figure 8. Moreover, given the slow rate at which coral communities fully develop, they may succumb to displacement by macro algae without human assistance. A study by Hughes (1994) in Jamaica estimated that macro algae have already become the dominant organism there with more than $90 \%$ presence compared to pre-1970 low estimates of about 5\% abundance.

\section{Conclusion}

Coral distribution can be largely affected by increases or decreases in their usual temperature range, which is mainly a function of how well coral symbionts can tolerate such deviation. In the Caribbean, most observed temperature anomalies have been associated with increase in temperature leading to mass bleaching events. Such temperature fluctuations are not unique and paleontological evidence shows that they also occurred during pre-Quaternary Phanerozoic time and affected both the paleo-latitudinal movement and diversity of coral. Many studies have reported on the association between coral niche and temperature range with some 
further investigating thermal thresholds for the onset of bleaching in the Caribbean, which has proven to be a very complex issue.

Based on past observations of bleaching events, it seems that the severity of coral bleaching events in the Caribbean has increased. This has brought about great concern in the coral science community with respect to the long-term health of coral reef ecosystems. This becomes even more of an issue due to the fact that the most conservative of IPCC RCP 2.6 predicts that in the next few decades, temperatures will increase by about 0.4 to $1.6^{\circ} \mathrm{C}$ during the period of 2046 to 2065 and further out to $1.7^{\circ} \mathrm{C}$ from 2081 to 2100 . These predictions also show that in the future most of the modern reef zone may be impacted by temperature increases.

In order to survive possible future increases in SSTs, corals may have to adapt, especially since few places are expected to be unaffected by changes in SSTs in the mid- to long-term future. Evidence suggests that some coral species may be able to adapt to temperature increases while others may become extinct. Recently, some corals have also shown signs of latitudinal shifting within only a few decades. These strategies, along with the ability to increase their rate of heterotrophic feeding, may further prolong extinction times. However, research has shown that only few corals have these abilities. Moreover, knowledge about the corals' ability to adapt to increasing temperature in the Caribbean is still unknown, an area requiring further investigation. Finally, it could be the case that more intervention on the part of humans will be needed in the future to help ensure that corals will continue to survive and grow. This includes better restoration management and policies designed to preserve and ensure the health of corals, the physical transplanting of corals to other locations in the case of severe bleaching events, and also the reduction and/or better management of activities which lead to the destruction of corals. Furthermore, in order to increase the accuracy of coral predictions, more work needs to be done 
within a relatively short period of time before many coral species in the Caribbean go extinct. There is hope that with better understanding of corals, scientists, governments, and other stakeholders will be better able to aid in coral conservation in the Caribbean and worldwide

\section{Acknowledgements}

The author would like to thank Rainah Mahabir of Hawthorne Elementary School, Hampton, Georgia, Atlanta for her kind assistance in making this research possible. Rainah helped collect information on relevant research and assisted with editing the bibliography and reviewing the final draft of this paper. 


\section{References}

Baker, A. C., Starger, C. J., McClanahan, T. R., \& Glynn, P. W. (2004). Coral reefs: Corals' adaptive response to climate change. Nature, 430, 741. doi:10.1038/430741a

Berkelmans, R. (2002). Time-integrated thermal bleaching thresholds of reefs and their variation on the Great Barrier Reef. Marine Ecology Progress Series, 229, 73-82. doi:10.3354/meps229073

Berkelmans, R., De'ath, G., Kininmonth, S., \& Skirving, W. J. (2004). A comparison of the 1998 and 2002 coral bleaching events on the Great Barrier Reef: Spatial correlation, patterns, and predictions. Coral Reefs, 23, 74-83. doi:10.1007/s00338-003-0353-y

Brown, B. E. (1997). Coral bleaching: Causes and consequences. Coral Reefs, 16, S129-S138. doi:10.1007/s003380050249

Brown, B. E., \& Ogden, J. C. (1993). Coral bleaching. Scientific American, 268(1), 64-70. doi:10.1038/scientificamerican0193-64

Buchheim, J. (1998). Coral reef bleaching. Odyssey Expeditions. Retrieved from http://www.marinebiology.org/coralbleaching.htm

Caribbean. (2006). In Wikipedia. Retrieved April 27, 2016, from https://commons.wikimedia.org/wiki/File:CaribbeanIslands.png

Cheung, W. W. L., Lam, V. W. Y., Sarmiento, J. L., Kearney, K., Watson, R. \& Pauly, D. (2009). Projecting global marine biodiversity impacts under climate change scenarios. Fish and Fisheries, 10, 235-251. doi:10.1111/j.1467-2979.2008.00315.x

Cole, A. J., Pratchett, M. S., \& Jones, G. P. (2008). Diversity and functional importance of coralfeeding fishes on tropical coral reefs. Fish and Fisheries, 9, 286-307. doi:10.1111/j.1467-2979.2008.00290.x

Coral Reef Alliance. (2008). Coral reef overview. Coral Reef Alliance. Retrieved from: http://www.coral.org/resources/about_coral_reefs/coral_overview\#whatpolyp

Donner, S. D. (2009). Coping with commitment: Projected thermal stress on coral reefs under different future scenarios. PLOS ONE, 4(6), e5712. doi:10.1371/journal.pone.0005712

Donner, S. D., Knutson, T. R., \& Oppenheimer, M. (2007). Model-based assessment of the role of human-induced climate change in the 2005 Caribbean coral bleaching event. PNAS, 104, 5483-5488. doi:10.1073/pnas.0610122104

Donner, S. D., Skirving, W. J., Little, C. M., Oppenheimer, M., \& Hoegh-Guldbergs, O. (2005). Global assessment of coral bleaching and required rates of adaptation under climate change. Global Change Biology, 11, 2251-2265. doi:10.1111/j.1365-2486.2005.01073.x

Dove, S. G., \& Hoegh-Guldberg, O. (2006). The cell physiology of coral bleaching. In J. T. Phinney, O. Hoegh-Guldberg, J. Kleypas, W. Skirving, \& A. Strong (Eds.), Coral reefs 
and climate change science and management (pp. 55-71). Washington, DC: American Geophysical Union.

Dubinsky, Z., \& Falkowski, F. (2011). Light as a source of information and energy in zooxanthellate corals. In Z. Dubinsky \& N. Stambler (Eds.), Coral reefs: An ecosystem in transition (pp. 107-118). doi:10.1007/978-94-007-0114-4

Eakin, C. M., Morgan, J. A., Heron, S. F., Smith, T. B., Liu, G., Alvarez-Filip, L., ... Yusuf, Y. (2010). Caribbean corals in crisis: Record thermal stress, bleaching, and mortality in 2005. PLoS ONE, 5(11), e13969. doi:10.1371/journal.pone.0013969

Fitt, W. K. \& Warner, M. E. (1995). Bleaching patterns of four species of Caribbean reef corals. Biological Bulletin, 189, 298-307. doi:10.2307/1542147

Garpe, K. C., Yahya, S. A. S., Lindahl, U., \& Öhman, M. C. (2006). Long-term effects of the 1998 coral bleaching event on reef fish assemblages. Marine Ecology Progress Series, 315, 237-247. doi:10.3354/meps315237

Gates, R. D., \& Edmunds, P. J. (1999). The physiological mechanisms of acclimatization in tropical reef corals. American Zoologist, 39, 30-43. doi:10.1093/icb/39.1.30.

Glynn, P. W. (1991). Coral reef bleaching in the 1980s and possible connections with global warming. Trends in Ecology and Evolution, 6, 175-179. doi:10.1016/01695347(91)90208-F

Glynn, P. W. (1996). Coral reef bleaching: Facts, hypotheses and implications. Global Change Biology, 2, 495-509. doi:10.1111/j.1365-2486.1996.tb00063.x

Glynn, P. W., \& D'Croz, L. (1990). Experimental evidence for high temperature stress as the cause of El Niño-coincident mortality. Coral Reefs, 8, 181-191. doi:10.1007/bf00265009

Golledge, N. R., Kowalewski, D. E., Naish, T. R., Levy, R. H., Fogwill, C. J., \& Gasson, E. G. W. (2015). The multi-millennial Antarctic commitment to future sea-level rise. Nature, 526, 421-425. doi:10.1038/nature15706

Goreau, T. J., Hayes, R. L., Clark, J. W., Basta, D. J., \& Robertson, C. N. (1993). Elevated sea surface temperatures correlate with Caribbean coral reef bleaching. In R. A. Geyer (Ed.), A global warming forum: Scientific, economic and legal overview (pp. 225-255). Boca Raton, FL: CRC Press.

Goreau, T., McClanahan, T., Hayes, R., \& Strong, A. (2000). Conservation of coral reefs after the 1998 global bleaching event. Conservation Biology, 14, 5-15. doi:10.1046/j.15231739.2000.00011.x

Grottoli, A. G., Rodrigues, L. J., \& Palardy, J. E. (2006). Heterotrophic plasticity and resilience in bleached corals. Nature, 440, 1186-1189. doi:10.1038/nature04565

Harley, C. D. G., Hughes, A. R., Hultgren, K. M., Miner, G., Sorte, C. J. B., Thornber, C. S., ...Williams, S. L. (2006). The impacts of climate change in coastal marine systems. Ecology Letters, 9, 228-241. doi:10.1111/j.1461-0248.2005.00871.x 
Henkel, T. P. (2010). Coral reefs. Nature Education Knowledge. Retrieved from http://www.nature.com/scitable/knowledge/library/coral-reefs-15786954

Hoegh-Guldberg, O. (1999). Climate change, coral bleaching and the future of the world's coral reefs. Marine and Freshwater Research, 50, 839-866. doi:10.1071/MF99078

Hoegh-Guldberg, O. (2011). The impact of climate change on coral reef ecosystems. In Z. Dubinsky \& N. Stambler (Eds.), Coral reefs: An ecosystem in transition (pp. 391-403). doi:10.1007/978-94-007-0114-4

Hoegh-Guldberg, O., \& Smith, G. J. (1989). Light, salinity, and temperature and the population density, metabolism, and export of zooxanthellae from stylophora pistillata and seriatopora hystrix. Journal of Marine Biology and Ecology, 129, 279-303. doi:10.1016/0022-0981(89)90109-3

Houlbrèque, F., \& Ferrier-Pagès, C. (2009). Heterotrophy in tropical scleractinian corals. Biological Reviews of the Cambridge Philosophical Society, 84, 1-17. doi:10.1111/j.1469-185X.2008.00058.x

Hughes, T. P. (1994). Catastrophes, phase shifts, and large-scale degradation of a Caribbean coral reef. Science, 265, 1547-1551. doi:10.1126/science.265.5178.1547

Hughes, T. P., Baird, A. H., Bellwood, D. R., Card, M., Connolly, S. R., Folke, C., ... Roughgarden, J. (2003). Climate change, human impacts, and the resilience of coral reefs. Science, 301, 929-933. doi:10.1126/science.1085046

Iglesias-Prieto, R., Matta, J. L., Robins, W. A., \& Trench, R. K. (1992). Photosynthetic response to elevated temperature in the symbiotic dinoflagellate symbiodinium microadriaticum in culture. PNAS, 89, 10302-10305. doi:10.1073/pnas.89.21.10302

International Coral Reef Initiative (ICRI) (n.d.). What are corals? Retrieved from http://www.icriforum.org/about-coral-reefs/what-are-corals

IPCC (2013). Summary for policymakers. In: T. F. Stocker, D. Qin, G.-K. Plattner, M. Tignor, S.K. Allen, J. Boschung, A. Nauels, Y. Xia, V. Bex, \& P.M. Midgley (Eds.), Climate change 2013: The physical science basis. Contribution of Working Group I to the Fifth Assessment Report of the Intergovernmental Panel on Climate Change. Cambridge, UK: Cambridge University Press.

IPCC. (2014). Climate change 2014: Synthesis report. Contribution of Working Groups I, II and III to the Fifth Assessment Report of the Intergovernmental Panel on Climate Change. Cambridge, UK: Cambridge University Press.

Kearney, M., \& Porter, W. (2009). Mechanistic niche modelling: Combining physiological and spatial data to predict species' ranges. Ecology Letters, 12, 334-350. doi:10.1111/j.14610248.2008.01277.x

Kiessling, W. (2001). Paleoclimatic significance of phanerozoic reefs. Geology, 29, 751-754. doi:10.1130/0091-7613(2001)029<0751:PSOPR >2.0.CO;2 
Lesser, M. P. (2007). Coral reef bleaching and global climate change: Can corals survive the next century? PNAS, 104, 5259-5260. doi:10.1073/pnas.0700910104

Lough, J. L. (2008). A changing climate for coral reefs. Journal of Environmental Monitoring, 10, 21-29. doi:10.1039/b714627m

Loya, Y., Sakai, K., Yamzato, K., Nakano, Y., Sambali, H., \& Van Woesik, R. (2001). Coral bleaching: the winners and the losers. Ecology Letters, 4, 122-131. doi:10.1046/j.14610248.2001.00203.x

McClanahan, T. R. (2004). The relationship between bleaching and mortality of common corals. Marine Biology, 144, 1239-1245. doi:10.1007/s00227-003-1271-9

McWilliams, J. P., Cote, I. M., Gill, J. A., Sutherland, W. J., \& Watkinson, A. R. (2005). Accelerating impacts of temperature-induced coral bleaching in the Caribbean. Ecology, 86, 2055-2060. doi:10.1890/04-1657

Mieog, J. C., Van Oppen, M. J. H., Cantin, N. E., Stam, W. T., \& Olsen, J. L. (2007). Real-time PCR reveals a high incidence of Symbiodinium clade D at low levels in four scleractinian corals across the Great Barrier Reef: Implications for symbiont shuffling. Coral Reefs, 26, 449-457. doi:10.1007/s00338-007-0244-8

Mulhall, M. (2009). Saving the rainforest of the sea: An analysis of international efforts to conserve coral reefs. Duke Environmental Law and Policy Forum, 19, 321-352.

Retrieved from: http://scholarship.law.duke.edu/delpf/vol19/iss $2 / 6$

NASA. (2011). Properties of fresh and sea water. NASA Aquarius. Retrieved from http://aquarius.nasa.gov

NOAA. (2009). Corals. NOAA Ocean Service Education. Retrieved from http://oceanservice.noaa.gov/education/kits/corals/media/supp_coral05a.html

NOAA. (2010). Hope in the face of a Caribbean coral crisis. Retrieved from https://www.climate.gov/news-features/features/hope-face-caribbean-coral-crisis

NOAA. (2015a). Coral anatomy and structure. Retrieved from http://coralreef.noaa.gov/aboutcorals/coral101/anatomy/

NOAA. (2015b). Climate model: Temperature change (RCP 2.6) - 2006-2100." Retrieved from http://sos.noaa.gov/Datasets/dataset.php?id=436

Palumbi, S. R., Barshis, D. J., Traylor-Knowles, N., \& Bay, R. A. (2014). Mechanisms of reef coral resistance to future climate change. Science, 344, 895-898. doi:10.1126/science. 1251336

Parmesan, C., \& Yohe, G. (2003). A globally coherent fingerprint of climate change impacts across natural systems. Nature, 421, 37-42. doi:10.1038/nature01286

Parry, M. L., Canziani, O. F., Palutikof, J. P., van der Linden, P. J., \& Hanson, C. E. (Eds.). (2007). Contribution of Working Group II to the Fourth Assessment Report of the 
Intergovernmental Panel on Climate Change, 2007. Cambridge, UK: Cambridge University Press.

Precht, W. F., \& Aronso, R. B. (2004). Climate flickers and range shifts of reef coral. Frontiers in Ecology and the Environment, 2, 307-331. doi:10.1890/15409295(2004)002[0307:CFARSO]2.0.CO;2

Reaka-Kudla, M. L. (1997). The global biodiversity of coral reefs: a comparison with rain forests. In M. L. Reaka-Kudla, D. E. Wilson, \& E. O. Wilson (Eds.), Biodiversity II: Understanding and protecting our biological resources (2nd ed.) (pp. 83-108). Washington, DC: Joseph Henry Press.

Rodríguez, S., Cróquer, A., Bone, D., \& Bastidas, C. (2010). Severity of the 1998 and 2005 bleaching events in Venezuela, Southern Caribbean [Supplemental Issue]. Revista de Biología Tropical, 58(3), 189-196. Retrieved from http://www.biologiatropical.ucr.ac.cr/

Rowan, R. (2004). Coral bleaching: Thermal adaptation in reef coral symbionts. Nature, 430, 742. doi:10.1038/430742a

Solomon, S., Qin, D., Manning, M., Chen, Z., Marquis, M., Averyt, K., ... Miller, H. L. (Eds.). (2007). Climate change 2007: The physical science basis. Contributions of Working Group I to the Fourth Assessment Report to the Intergovernmental Panel on Climate Change. Cambridge, UK: Cambridge University Press.

Spalding, M. D., Green, E. P., \& Ravilious, C. (2001). Defining coral reefs. In World atlas of coral reefs (pp. 20-42). Berkeley, CA: University of California Press.

Stern, N. (2007). The economics of climate change: The Stern review. Cambridge, UK: Cambridge University Press.

Symon, C. (2013). Climate change: Action, trends and implications for business. Cambridge, UK: Cambridge University Press.

West, J. M., \& Salm, R. V. (2003). Resistance and resilience to coral bleaching: Implications for coral reef conservation and management. Conservation Biology, 17, 956-967. doi:10.1046/j.1523-1739.2003.02055.x

Wilkerson, F. P., Kobayashi, D., \& Muscatine, L. (1988). Mitotic index and size of symbiotic algae in Caribbean reef corals. Coral Reefs, 7, 29-36. doi: 10.1007/BF00301979

Wilkinson, C., Linden, O., Cesar, H., Hodgson, G., Rubens, J., \& Strong, A. E. (1999). Ecological and socioeconomic impacts of 1998 coral mortality in the Indian Ocean: An ENSO impact and a warning of future change?" Ambio, 28, 188-196. Retrieved from http://www.jstor.org/stable/4314874

Williams, E. H., \& Bimkley-Williams, L. (1990). The world-wide coral bleaching cycle and related sources of coral mortality. Atoll Research Bulletin, 335, 1-71.

doi:10.5479/si.00775630.335.1 
Wood, R. (1999). The role of physicochemical change. In Reef Evolution (pp. 123-164). Oxford, UK: Oxford University Press. 
Tables and Figures

Table 1

Projected Change in Global Mean Surface Temperature

\begin{tabular}{|c|c|c|c|c|c|}
\hline & & \multicolumn{2}{|c|}{$2046-2065$} & \multicolumn{2}{c|}{$2081-2100$} \\
\hline & Scenario & Mean & Likely range & Mean & Likely range \\
\hline \multirow{3}{*}{$\begin{array}{c}\text { Global average surface } \\
\text { temperature change }\left({ }^{\circ} \mathrm{C}\right)\end{array}$} & RCP 2.6 & 1.0 & 0.4 to 1.6 & 1.0 & 0.3 to 1.7 \\
\cline { 2 - 6 } & RCP 4.5 & 1.4 & 0.9 to 2.0 & 1.8 & 1.1 to 2.6 \\
\cline { 2 - 6 } & RCP 6.0 & 1.3 & 0.8 to 1.8 & 2.2 & 1.4 to 3.1 \\
\cline { 2 - 6 } & RCP 8.5 & 2.0 & 1.4 to 2.6 & 3.7 & 2.6 to 4.8 \\
\hline
\end{tabular}

Note: Adapted from "Summary for Policymakers," by IPCC, 2013 in T. F. Stocker, D. Qin, G.K. Plattner, M. Tignor, S.K. Allen, J. Boschung, A. Nauels, Y. Xia, V. Bex, and P.M. Midgley (Eds.), Climate change 2013: The physical science basis. Contribution of Working Group I to the Fifth Assessment Report of the Intergovernmental Panel on Climate Change, p. 21. 


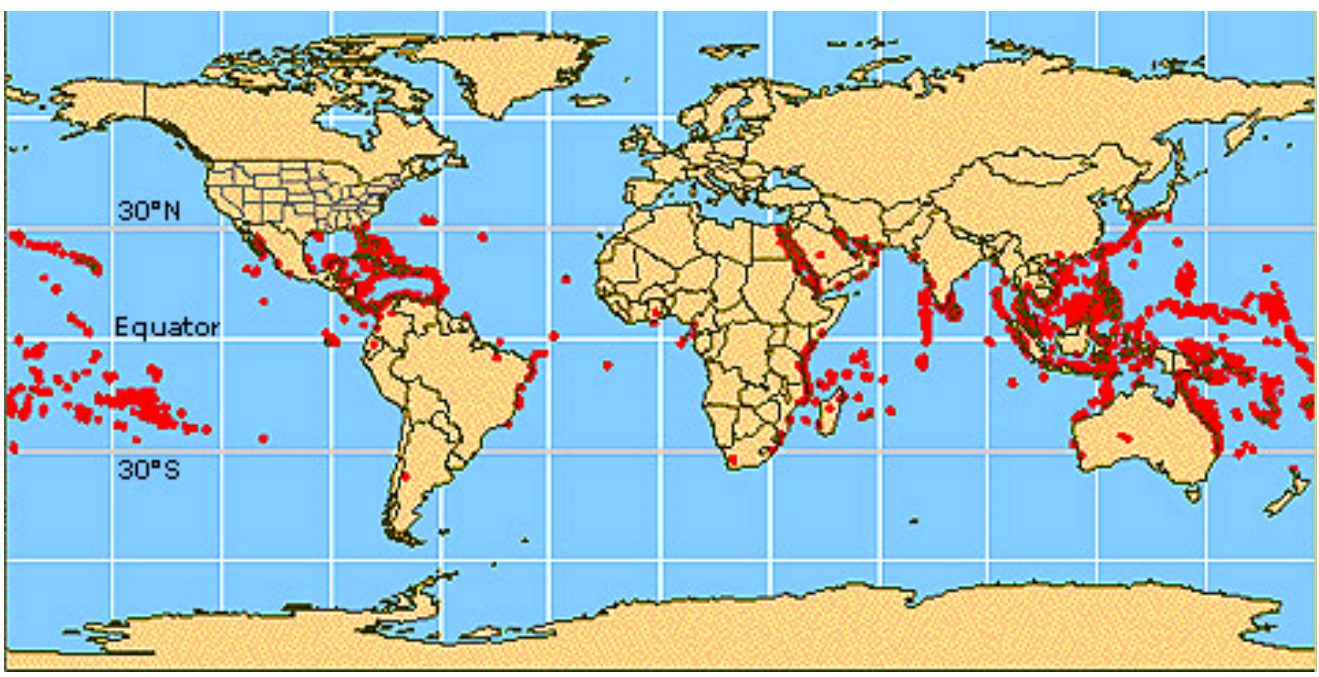

Figure 1. Distribution of coral reefs globally. From "Corals," by NOAA, 2009, NOAA Ocean Service Education. Retrieved from http://oceanservice.noaa.gov/education/kits /corals/media/supp_coral05a.html

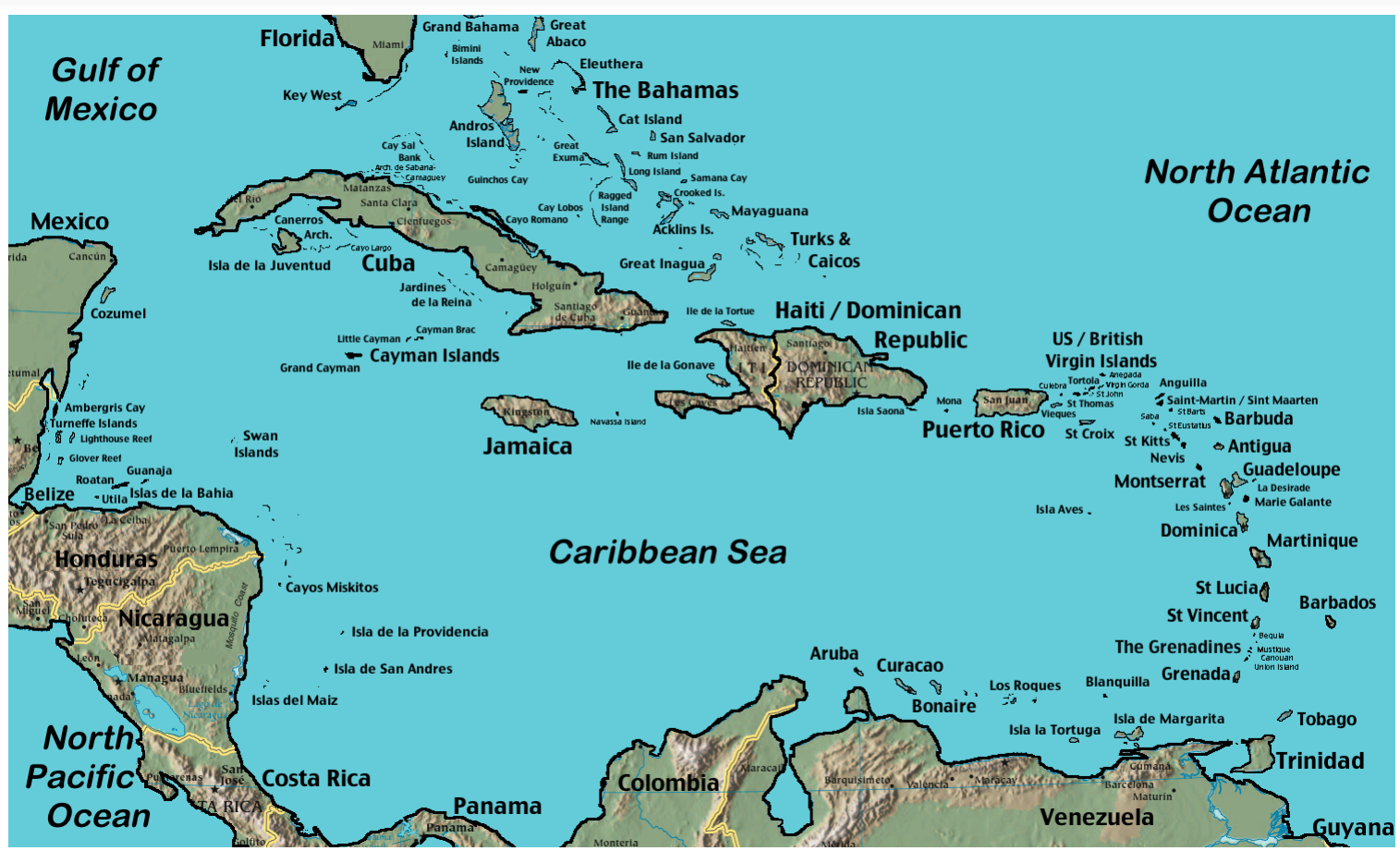

Figure 2. Map of the Caribbean. From "Caribbean," 2006, Wikipedia. Retrieved April 27, from https://commons.wikimedia.org/wiki/File:CaribbeanIslands.png 


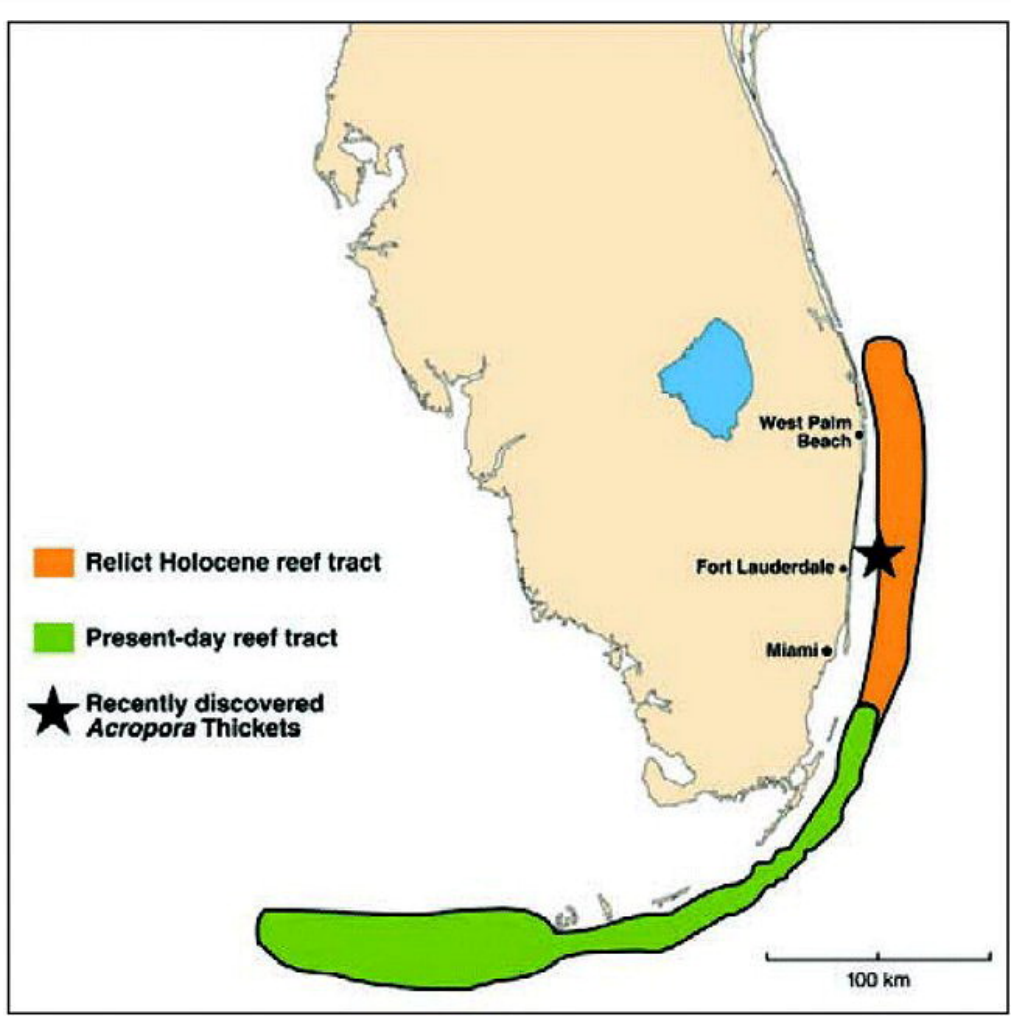

Figure 3. Map of Florida showing the present-day distribution of the reef tract and the northern limit of acroporid corals (green), the relict Holocene reef tract dominated by acroporid corals (orange). From "Climate Flickers and Range Shifts of Reef Coral," by W. F. Precht and R. B. Aronso, 2004, Frontiers in Ecology and the Environment, 2, p. 309. Copyright by the Ecological Society of America. 


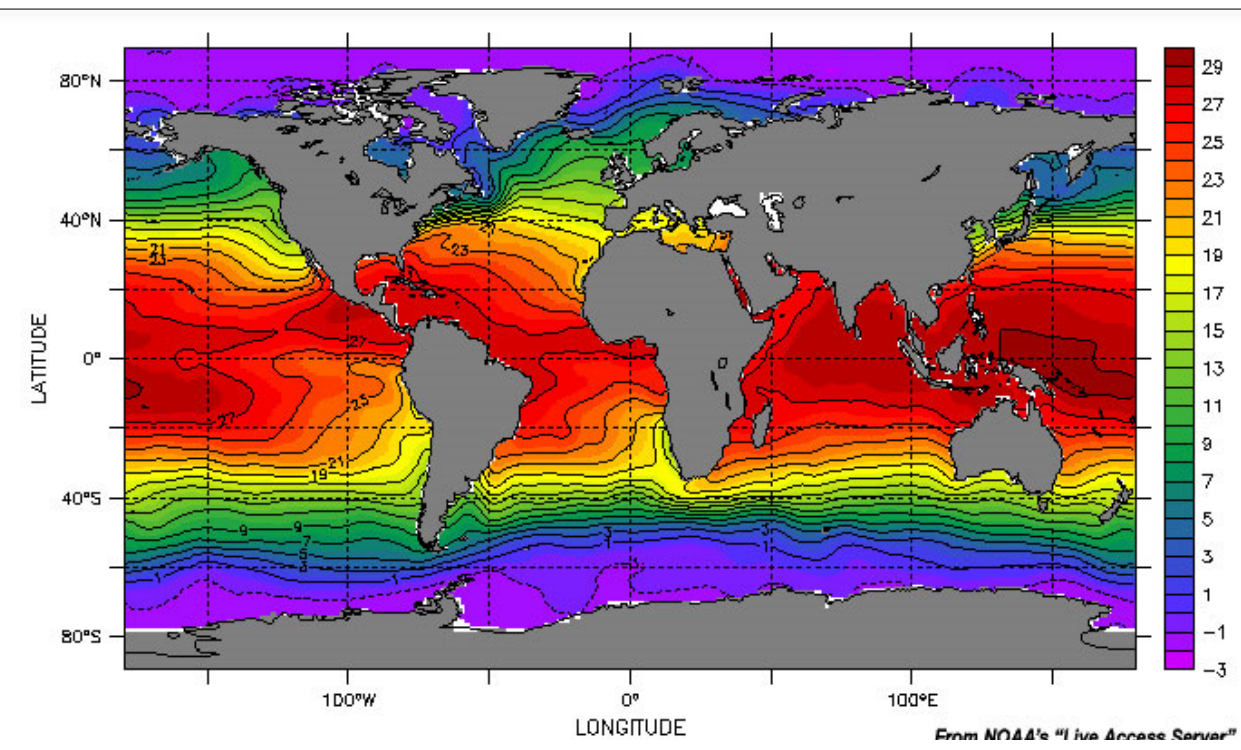

Figure 4. Average sea surface temperature $\left({ }^{\circ} \mathrm{C}\right)$. From "Properties of Fresh and Sea Water," by NASA, 2011, NASA Aquarius. Retrieved from http://aquarius.nasa.gov

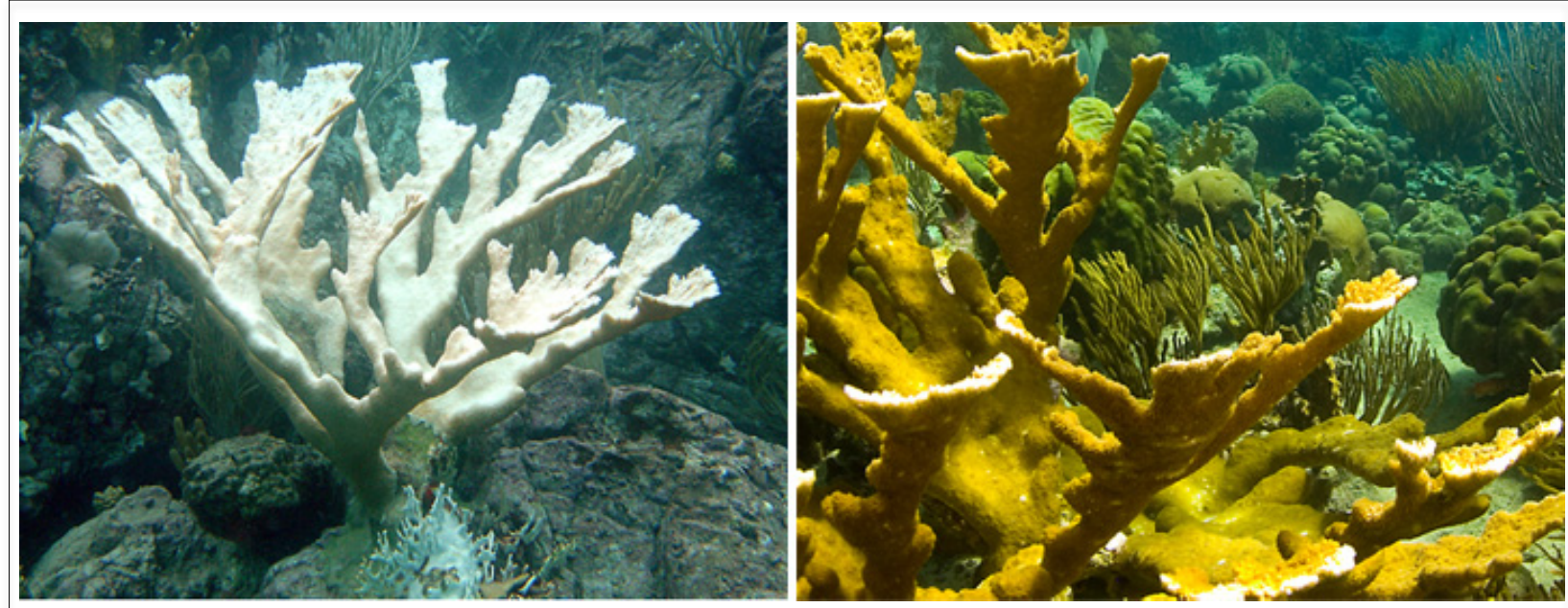

Figure 5. A bleached elkhorn coral (Acropora palmata) in the U.S. Virgin Islands in 2005 (left) compared to the species' normal color (right, not same coral). Reprinted from "Hope in the Face of a Caribbean Coral Crisis, by NOAA, 2010. Retrieved from https://www.climate.gov/news-features/features/hope-face-caribbean-coral-crisis 


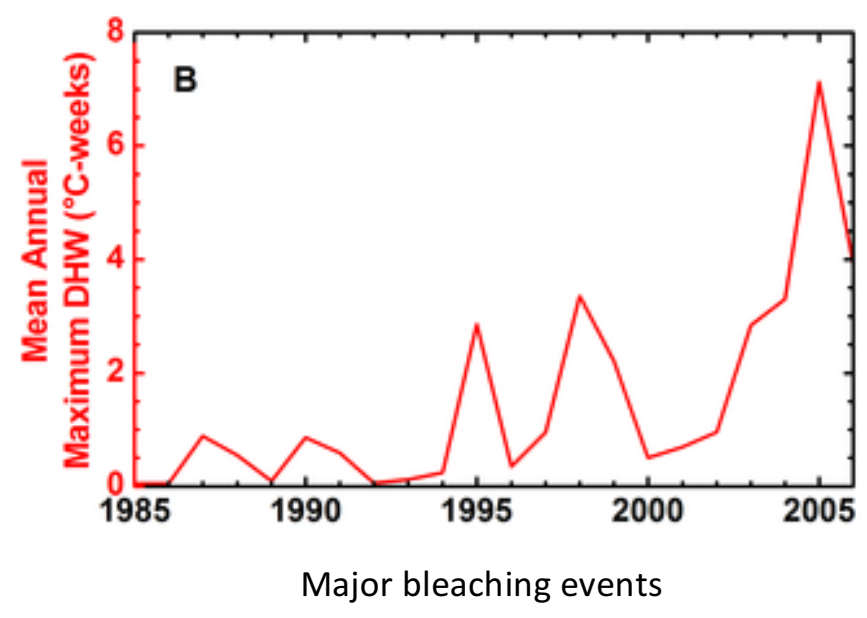

Figure 6. Mean annual increase in temperature (1985-2006) for the Caribbean. From "Caribbean Corals in Crisis: Record Thermal Stress, Bleaching, and Morality in 2005," by C. M. Eakin, J. A. Morgan, S. F. Heron, T. B. Smith, G. Liu, L. Alvarez-Filip, ... Y. Yusuf, 2010, PLoS ONE, 5(11), e13969, p. 3.

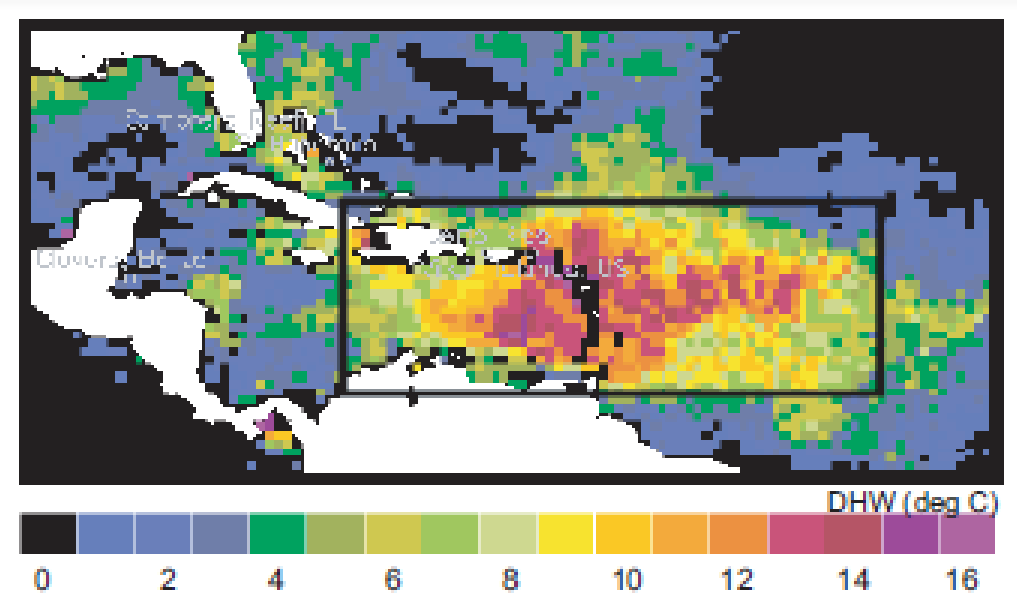

Figure 7. Satellite-observed thermal stress on Caribbean (marked within black line) coral reefs Map of 2005 maximum thermal stress, expressed as degree heating weeks $\left({ }^{\circ} \mathrm{C}\right.$ week). From "Model-Based Assessment of the Role of Human-Induced Climate Change in the 2005 Caribbean Coral Bleaching Event" by S. D. Donner, T. R. Knutson, and M. Oppenheimer, 2007, PNAS, 104, p. 5484. Copyright in 2007 by the National Academy of Sciences of the USA. 


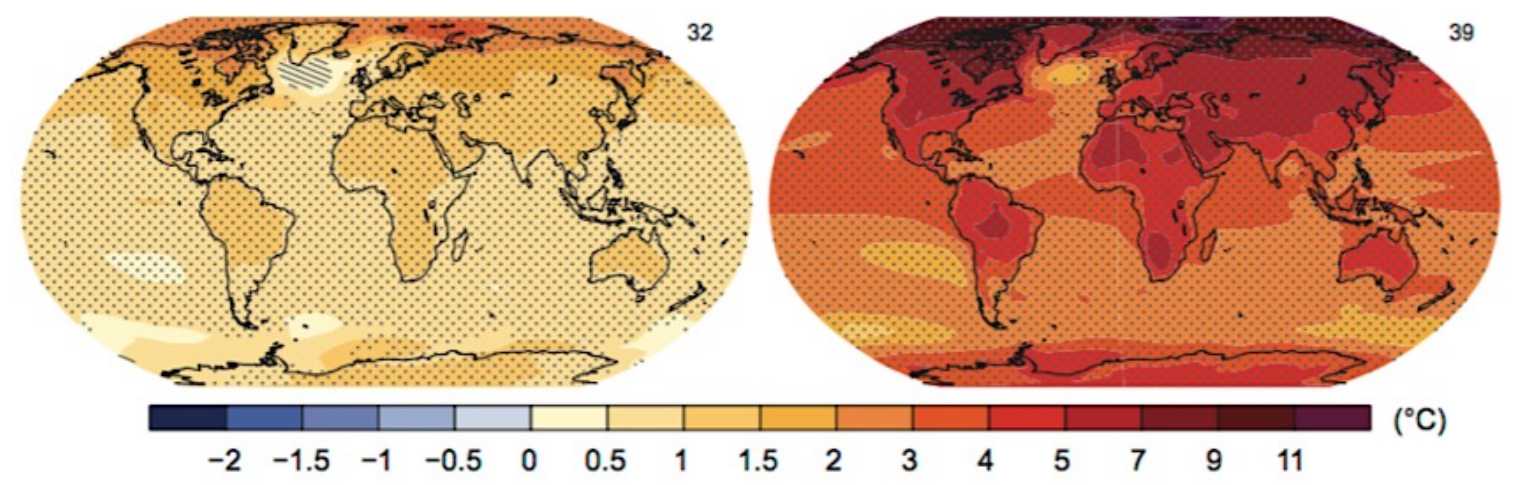

Figure 8. Change in average surface temperature (1986-2005 to 2081-2100). From "Summary for Policymakers," by IPCC, 2013 in T. F. Stocker, D. Qin, G.-K. Plattner, M. Tignor, S.K. Allen, J. Boschung, A. Nauels, Y. Xia, V. Bex, and P.M. Midgley (Eds.), Climate change 2013: The physical science basis. Contribution of Working Group I to the Fifth Assessment Report of the Intergovernmental Panel on Climate Change, p. 22. 